\title{
Future Scenarios for United Europe
}

\author{
Alberto GASPARINI
}

\begin{abstract}
In the paper the United Europe, in the shape of EU, is described, but also the "cracks" ongoing inside it: first of all the European economic crisis that does not allow to practice a positive internal "soft power", the lack of charismas of the EU élites, the mechanisms of government that weaken the capacity of EU to be effective (for example the rotation of the presidency, creeping internal colonialisms, and so on) are considered. Starting from this present scenario, scenarios for the future are worked out. We can define them in the following ways: 1) the pure catastrophic scenario: it sees the disappearance of the United Europe or this becomes an empty shell; 2) the realistic catastrophic scenario: it sees the United Europe to become an entity in which internal asymmetrical relations take form, completely open towards the strongest states and close enough (for the circulation and rules) towards the internal peripheral or smaller states or more little, operating a kind of colonialism; 3) the realistic ideal scenario: it sees that the United Europe keeps the "promises" made and the "premises" from which it is born, except that its member states are still strong and their "reserve of powers". Outwards the EU always remains and keeps the features of an International Organisation; 4) finally the pure ideal scenario: it sees the transformation of the EU in a federal state, in which the sovereignty of the federate state remains more and more soft so much that it disappears, at least in the aspects of general coordination and of the management of the EU general policies. The discussion of the four scenarios verifies which of them will be carried out in the future: after 10 years, 20 years, 30 years. 40 years. It is more likely that the fifth scenario occurs, that is a scenario that collects elements from each of the scenarios considered before and it assumes a further configuration with respect to those are forecast.
\end{abstract} Keywords: United Europe, scenarios, future, civil society, social integration

\section{Current scenario for the United Europe: problems and impasses}

The present-day is a Europe that offers many advantages, of course, but it also faces a number of problematic situations, all of which can be traced to a number of essential fixed points: the value of domestic peace but also of international peace, the original value of civil society extended to all societies in the manifestations of everyday life, the mixing of civil societies; a single political society which is not easy to construct because single states still exist, but also because this Europe displays a kind of addiction to a system, formerly bi-polar and now mono-polar, in which it has difficulty in identifying its post-imperial "wisdom".

The fusion of the above fixed points will produce the future Europe, but it will also produce the problems it must face and the opportunities that new and external developments will present it with. I shall now mention some of them.

1) The balance between the civil societies of each of the 28 nations and the civil society of the new European Union is fairly predictable and in some ways the element whose construction is most simple. The Union has a consolidated tradition of 
attention and action for standardising civil societies and opening them to dialogue. Community directives, and recommendations which become obligatory, have played a fundamental role in this construction - in the economy, the single currency, human and civil rights, culture, the widespread execution of public works that the poorest countries would otherwise be unable to achieve (in Portugal, Ireland, Greece, southern Italy and Spain), the devolution of central power to the (Euro)regions ${ }^{1}$, and the progressive weakening of national sovereignty, at least inasmuch as it impinges on civil society. There is no doubt that the entry of new countries in the EU - and subsequently of other candidates and candidates-to-be, all with a centralist, egalitarian and Communist history behind them - will pose enormous problems of harmonisation and require a great deal of time. ${ }^{2}$

2) The present European Union is a product of civil society, a collection of social groups, organisations and associations governed by the interests and rights of the individual, of all individuals. It must now be added that a national social system can maintain itself and its international relations (especially the most demanding ones) only if the various components of civil society give their consent to the political class which has made strategic choices for the country. The strategic choice in this case is to take the country into the European Union. What happens if the consent given to the political elite is removed? The result will be new governments, which may be populist or neo-Communist in character. This will produce the temptation, if not the actual move, to leave the united Europe. This is not a very likely scenario, because the accession of the former Communist countries was based on a sort of pact between their citizens and their governments and the EU: you make sure we get a good quality of life, full employment and self-fulfilment in the market through privatisation, and we shall succumb to the allure of being part of the New United Europe. ${ }^{3}$

3) What European civil society may arise from relations between the many old and new national civil societies, and therefore from the policies of the new European Union? Broadly speaking, the new countries exert a form of historical attraction on the societies of Mitteleuropa and Scandinavia, so they will to some extent strengthen their economic, cultural and social ties with countries of German or Scandinavian culture. This will cause imbalances among the various souls of Europe, with the reinforcement of the German-influenced Nordic soul at the expense of the Latin and Mediterranean souls, and to some extent even the English-speaking one. The result might be latent conflicts arising from the tendential formation of central and peripheral circles in the united Europe. This drives the marginal countries to pull into Europe not only the Balkan-Danube countries but also those of the Mediterranean area, starting with the now-consolidated

1 Gasparini, 2007, pp. 9-40; Gasparini, 2012, pp. 17-32.

2 Gasparini and Radojkovic, 1994; Petrovic and Russo, 1998; Puscas , 2006; Puscas, 2013; Kornai, 2008; Dolghi, Rouet and Radics, 2009.

3 Hughes, 1999; Baldocci and Gasparini, 2007; Sidjanski, 2007, pp. 87-110. 
Turkey and proceeding with the Arab and Maghreb countries in North Africa. The momentum will thus tend towards a further enlargement of Europe, which will in turn create new dynamics and new balances.

4) These political processes are made all the more complex by the lack of any precedent. It will take a long time for coalitions to form and consolidate, if they ever do. This complexity and the long-time scales involved in the preparation and taking of decisions (which also entail the time needed for the formation of consensus and convergence) absorb a great deal of energy and tension and too much attention, which works heavily to the detriment of the external role that the new European Union is called upon to play. And that handicap is further compounded by the fact that the European Foreign Minister is an entirely new figure, one whose independence from 28 national governments will have to be established. All this leads to the conclusion that for many years to come this European Union will unable to play an international role, one that would enact the consolidated values of the European peoples - that of peace as a basis on which to deal with conflicts (to be maintained at a virtual, sublimated level) and that of the "imperial wisdom" that Europe seems to have accumulated from its tragic imperialist past. ${ }^{4}$

\section{Scenarios in 2050 for a united Europe of civil societies}

Thus far we have outlined the present United Europe scenario, which is very similar to the neo-functionalist model conceptually developed by Haas ${ }^{5}$ and Lindberg ${ }^{6}$ and updated in the 1990s and the following decade by Gehring ${ }^{7}$ and Sandholtz and Stone Sweet ${ }^{8}$. Neo-functionalism "describes and explains the process of regional integration with reference to how three causal factors interact with one another: 1) growing economic interdependence between nations, 2) organizational capacity to resolve disputes and build international legal regimes, and 3) supranational market rules that replace national regulatory regimes. ${ }^{9}$

We have also identified the problems encountered by the scenario in maintaining Europe united in the immediate future, and in the deeper future of the next few decades. These futures are projected at times between 2020 and 2050. The first step is to define what the United Europe scenarios are, and then they are projected into the years comprised between 2020 and $2050 .{ }^{10}$

4 Rinaldi, 1995, pp. 327-350; Gasparini, 2004b, pp. 73-98; Balsocci and Gasparini, 2007.

5 Haas, 1958.

6 Lindberg, 1963.

7 Gehring, 1996, pp. 225-253.

8 Sandholtz and Stone Sweet, 1997, pp. 297-317.

9 Haas, 1961, pp. 366-392; Sandholtz and Stone Sweet, 1997, pp. 297-317.

10 Gruppo di Lisbona, 1994; Baletic, 1998; Hughes, 1999; Gasparini and Bregantini, 2004, pp. 264-305; Radermacher 2004, pp. 188-207; Bauman, 2005, pp. 269-293; Gasparini, 2011, pp. 149-180; Randers, 2013. 
There are four types of possible scenario, within one of which Europe may evolve in a linear and continuous fashion, but it may also pass from one to another, at times quite easily - as will be seen in an attempt in the next section to introduce the time variable into each of the four scenarios. Now for their definition.

Starting from a scenario analysis conducted in 2000 for countries yet to join the European Union, considered according to their degrees of openness to the outside $^{11}$, the scenarios may be denominated as follows:

1. Pure catastrophic scenario,

2. Realistic catastrophic scenario,

3. Realistic ideal scenario,

4. Pure ideal scenario.

In which

Catastrophic means a negative scenario contrasting with a previous positive situation and unable to produce a positive future, which thus becomes impossible.

Ideal means a positive scenario following a previous positive situation, able to produce a positive future, in fact tending to produce the best outcome.

Realistic means a scenario where the implementation of policies makes it possible to approach the best outcome, with use of sustainable resources. Such policies are pursued without subjecting the population to excessive sacrifices.

Pure means a scenario where the policies implemented make it possible to achieve the best outcome.

Each of the four scenarios is considered according to the following criteria:

1. Each scenario is dominated by a principle, which is conducive to the materialisation of one type of model.

2. In each scenario there is an economic balance/imbalance within the United Europe and its single states, with a specific internal soft power. ${ }^{12}$

3. The third criterion concerns European integration as contrasted with national integration, with intermediate forms of European areas.

4. The fourth criterion concerns the localisation of the "reserve of powers".

5. The fifth criterion concerns relations between public opinion, the population, elites and states, and their movements (which may or may not be migratory). ${ }^{13}$

6. The sixth criterion concerns United Europe's relations with the outside world; it may behave as an international organisation, developing its own foreign policy according to the method of an external soft power. ${ }^{14}$

7. The seventh criterion emphasises the role of national civil societies and the United Europe.

Broadly following the above criteria, the four scenarios may now be defined.

11 Gasparini, 1999; Gasparini, 2004c; Ash , 2005, p. 203ss; Langer, 2011, pp. 31-60.

12 For example of Russia and China, see Wilson, 2012.

13 Scartezzini, 2002, pp. 377-400; Mon tanari, 2004, pp. 43-72.

14 Nye, 2005. 


\subsection{Pure catastrophic scenario or regression to states}

The principle dominating the catastrophic scenario is the reversion to original statehood. This is triggered by economic crisis, with a consequent plummeting of employment and incomes. The European Union is increasingly impoverished because the biggest and strongest states progressively reduce their budget contributions and the smaller and peripheral states therefore receive progressively fewer resources from the EU. National policies come to prevail over European policy and thus empty the United Europe of substance. Examples may be seen in the form of Hungary, the Czech Republic and the Poland of the Kaczynski brothers. The basic idea is "national is good", because the supranational EU is a source of discrimination and new vested interests. The latter include the European financial institutions, military power concentrated above all in French and British hands, internal alliances which further marginalise small states and make them increasingly insignificant. The ultimate "reserve of powers" is taken back by the states, including those which had already been devolved to the United Europe (previous non-compliance with the delegation of powers had been met with economic sanctions by the EU). European civil society fails, giving way to a reassertion of the overweening power of the civil societies of single states, and niche development as a consequence of national closure (whether imposed or chosen).

This scenario follows what Sandholtz and Stone Sweet ${ }^{15}$ and Rosamond ${ }^{16}$ call the intergovernmental model. This approach is based on the rationale that national states do preserve their core sovereignty while interacting among each other in search of results which satisfy their personal interests. National sovereignty represents the guarantee that common objectives and the integration process will respect the position of each member. Furthermore sovereignty constitutes a fundamental element for the existence of a national state. ${ }^{17}$ According this view the European Union should function as an ordinary international organisation in which the supranational power might exist in a weak form and in any case controlled by national interests.

In sum, this catastrophic scenario, more negative than the present scenario and unable to take a positive turn for the United Europe, is also pure because it is a reversion to single states after a time in which the United Europe model was believed in and experienced, only to be superseded by the frustration caused by its failure.

15 Sandholtz and Stone Sweet, 1997, pp. 297-317.

16 Rosamond, 2000, p. 132.

17 Albertini, 1997; Geertz, 1998, pp. 33-56; Acemoglu and Robinson, 2013. 


\subsection{Realistic catastrophic scenario or return to the Free Trade Area}

This scenario tends to empty the present United Europe of substance, turning into the North European idea of a Free Trade Area while preserving a simulacrum of United Europe, or perhaps a sort of "Dieta perpetua". ${ }^{18}$ In these conditions Europe's internal soft power, meaning the exercise of power by mediation and discussion, is unable to mediate the interests of EU member states and promote and equal and balancing integration of the diversities and differing levels of wealth of the European regions and social classes. Instruments such as free movement within the Schengen area, the Eurozone, structural projects, student exchanges and joint scientific research become increasingly exceptional in their adoption and effectiveness. In this scenario the EU also reduces integration and expands the accession of new states such as Belarus, the Ukraine, Moldova, Turkey, Balkan countries and states in the Mediterranean area. This leads to the creation of subareas of free trade: central-northern Europe (France, Benelux, Germany, Poland, the Czech Republic, Slovakia, Hungary), northern and Scandinavian Europe, south-eastern Europe (Balkan-Danube countries) and maritime southern Europe (Greece, Turkey, Italy, Spain, Portugal, Malta, Cyprus, the Middle East and North Africa). Norway becomes the reference model. The constraints of the United Europe are relegated to a discretional level, being adopted only according to national interests. The expansion of the Schengen area is stopped, partly because some countries refuse to take part (United Kingdom) and partly because others are refused entry to it, at least in the short to medium term. In external relations the United Europe behaves 1) as an international organisation in politics for lesser things (such as peacekeeping) and using international soft power in the economy and civil society; 2) as though it were non-existent for business of the greatest interest to the EU's stronger states - as in the cases of Libya and Mali. Lastly, national civil societies tend to maintain their current levels, with the class-based difference that European space is much easier to penetrate for elites (for study and tourism) and for the strongly empathetic poor, through immigration to European places representing the values that matter, than for autochthonous intermediate classes and the local poor, who remain in their national environments.

From a theoretical standpoint this scenario is more closely tied to the neo-functionalist approach already considered for the present scenario, highlighting the importance of regional integration and the pursuit of every national interest on the part of single states.

In sum, the realistic catastrophic scenario involves the disappearance of values, policies, global integration and economic balance, and the United Europe thus emptied is a shell within which a Free Trade Area takes shape. With the integration of the United Europe thus severely undermined, greater substance is taken on by

18 Ferraris, 2001, pp. 74-85. 
relations with non-EU countries and sub-areas within the present EU. The external borders of what is now the United Europe thus become weaker than they are now, whereas the borders between the sub-areas taking shape in the present EU become more rigid. Lastly, there occurs a split between national civil societies: those more closely identified with elites and poor non-European classes and young people who emigrate become (or remain) European civil societies, while those more identified with intermediate classes and the dignified autochthonous poor increasingly become national civil societies.

\subsection{Realistic ideal scenario or in equilibrium between political Europe in the short term and a federation in the long term}

The realistic ideal scenario rests on a principle which is ambivalent in terms of objectives to be pursued and dynamic over time. The aim is to take the present economic EU of civil societies towards a politically United Europe, beyond which is the more general objective of United Europe as a unitary state in the form of a confederation of states. This result is attempted through internal soft power, but its processes are too long for decisions which lead to radical changes, in particular in foreign policy (as shown by the cases of Iraq, Libya and Mali). Compared to the realistic catastrophic scenario, in this the variable geometries between EU countries (the current 27 plus Croatia) are less marked, because both the Schengen area and the Eurozone expand, and progressive European integration counteracts the formation of internal sub-areas (characterised by variable geometry). Favouring all this is the fact that discussions take place within established community bodies strengthened by cogent objectives. In addition, internal borders become increasingly redundant and virtual. By contrast, there is a marked tendency towards a rejection of the extension of the EU to countries still not in it, and a consequent hardening of neighbouring borders. Despite all the above, there remain strong contrasts between elements of public opinion (Europhiles against Eurosceptics) and their elites (more Euro-positive), and between states wanting greater integration and those wanting a loosening of internal integration and the common foreign policy.

In sum, the realistic ideal scenario has the positive orientation to enhance integration and limit the principle of variable geometries. The timescale for federation is still a long one and at times there are imbalances between elites favourable to Europe and national populations more interested in the practical benefits that the European Union can provide and the sacrifices it entails than the generic idea of a United Europe. On the other hand, the dominant model in the scenario is based on the syncretic paradigm. The "syncretic paradigm premised its assumptions about the dynamics behind regional change on ambivalence rather than certainty outcomes. The present standoff between the member states and those actors who steer 
the Community's supranational institutions simply could not be explained exclusively in realist or supranational terms". ${ }^{19}$

\subsection{Pure ideal scenario or a new federal state}

The strong guiding principle for this scenario is the aim of transforming the European Union into a federation of states. Recognising the internal powers of the federated states, the Union has the responsibility for the formation and imposition of general directives of economic, fiscal, monetary, environmental, transport, education, employment and foreign policy. The EU federal state is thus able to benefit from the time and resources previously devoted to decisions requiring a great deal of discussion, establishes a global society and free economies through internal soft power and also works through strong and effective international soft power. Territorial constraints (that is to say borders ${ }^{20}$ within the EU become increasingly administrative rather than political. Its external borders harden, but in these areas cooperation policies reduce the marginalisation of peripheral countries (with ECTCs, Euroregions, etc.). ${ }^{21}$ The EU establishes instruments which tend to reduce the marginalisation of areas and societies which may derive from the absence of national states which compensated for the differences within them. National states become regions in their present configuration and inherit their functions - in the case of medium-sized states they function as macro-regions, and small states are aggregated to their larger neighbours. The civil societies of single national states tend to fuse in a single European civil society through the achievement of a common and homogeneous integration of the human, civil and organisational rights of citizens belonging to the EU. Some specific characteristics peculiar to certain local and/or national societies continue to be recognised.

The pure ideal scenario ${ }^{22}$ achieves the ultimate and traditional aim of the United Europe of civil societies - a federal Europe, which is a single state but also a body of regional/state rights and duties which are perfectly recognised and implemented. The theoretical approach underlying this scenario is thus the federal one, which highlights "the priority to start making formal changes in political institutions and procedure as the key to securing social harmony and democracy. As a political doctrine, federalism has until quite recently always been more preoccupied by defining formal outcomes and recommending suitable institutional frameworks for balancing natural social diversity with the requirements for a just governance". ${ }^{23}$

19 O’Neill, 1996, p. 19ss.

20 Rifkin, 2002, p. 202.

21 Gasparini, 2012, pp. 17-32.

22 Bocchi, Ceruti and Morin, 1991, pp. 51-81; Fine, 2007, p. 48ss; Miglio and Barbera, 2008.

23 O’Neill, 1996, p. 19ss. 
The materialisation of this this scenario entails a high level of commitment to the objective but also to internal integration and equilibrium and a curtailment of the selfish interests of the single states making up the EU. It also requires the maintenance of a constant consensus based on practical responses to the needs and problems of civil societies. This scenario constitutes the realisation of the dream of a United Europe, the culmination of a process begun a long time ago by Spinelli ${ }^{24}$; but also Gatto 25 , De Gasperi, Monnet and Adenauer. We know, however, that the creation of this federation of states is not a final achievement, it is not a Europe united once and for all. History continues and the process of things goes on, so the commitment must be constant and efforts will have to be maintained to keep Europe united, modifying specific features and having to adapt to continually changing internal circumstances. Under these conditions the danger that this United Europe could enter into crisis and see the beginning of its decline is always present. It hardly needs to be said that such events have been seen many times in the past.

\section{The four scenarios in the temporal process from 2010 to 2050}

The four scenarios illustrated above represent the concluding point of a given period, which may be postulated to finish in 2050. It may also be considered as the reference point for a process of actions and policies which are introduced to modify the current scenario, the state of things as they now stand. As is well known, the business of prediction is not a utopian exercise. What is important in prediction is how the predicted future is constructed, that is to say the collection of actions and policies which in a given period are successively adapted in order to reach the desired (normative) prediction. By contrast, how a utopia is achieved matters little - what counts is the final state, which must be a perfect and unchangeable condition. ${ }^{26}$

If at the end of the given time-frame the four scenarios prove not to match the predictions made, this will be because more attention has been devoted to the process (the how mentioned above) than to the perfection of the predicted final state. In these conditions the future takes different forms, and is varyingly predictable, according to the times considered (the distance between $t_{0}$ and $t_{1}$ ). A prediction is more reliable if the time is short (a survey drawing on a short time-frame gives a more "certain" prediction), while a prediction is more uncertain and generic when time-frames are longer. In the case of United Europe four times are considered; over short time-frames the environment (context) is stable and the endogenous United Europe variables are more effective - the opposite is the case when the prediction times are longer.

24 Spinelli, 2010, pp. 39-72.

25 Gatto, 1995.

26 See Gasparini, 2000, pp. 2224-2233. 
For United Europe the operational environments for the four time-frames considered ${ }^{27}$ are as follows:

$-2020 \rightarrow$ stable environment,

$-2030 \rightarrow$ an environment with "creaks" and "noises", that is to say with modifications that produce some secondary effects of outward and inward adjustment for United Europe,

$-2040 \rightarrow$ an environment undergoing changes, some of which are radical,

$-2050 \rightarrow$ an environment with unpredictable radical changes.

The extreme scenarios (pure catastrophic and pure ideal) may be described as "movementist"; since they are orientated towards radical internal change in comparison with the current scenario (2010) and require strong and continual intervention policies. The first scenario of regression to states (pure catastrophic) is the result of the centre's inability to adopt community policies and the adoption by states of strong self-interested policies. The fourth scenario of the new federal state (pure ideal) is the result of "extreme" highly targeted community policies. But it is above all the result of policies leading to internal changes: United Europe's internal structure changes radically with the disappearance of the European Council and its representation of state decision-making power and with the establishment of the Euro as the state currency.

In these conditions the intermediate scenarios are more realistic, in that: 1) they entail fewer sacrifices for states (above all financial, connected to the criteria to which they have to conform) and for some social and particularly economic classes, which should face a number of "pressing" directives; 2) they are subject to ambivalent policies (or even contradictory between state and community level), unclear policies subject to discretional application and policies which may become contradictory in their sequencing over time. The latter contradiction is due to the fact that over time these scenarios are subject to policies which take varying lengths of time to be implemented or have to be adjusted or supplemented over time with other policies.

Another cause of these difficulties may be that strong (or central) states want certain policies and weaker ones (in terms of economy and status) want others. Or there may be a clash between the United Kingdom, the Czech Republic and Hungary (for example), which want a weakly united Europe, and other states which want a stronger United Europe more generous with money and investment and more open to free movement.

The following question may also be asked: what happens when the federal state of Europe has been achieved, even before the forty-year timescale has elapsed? It has already been seen that such an institutional arrangement is unlikely to be perfect, since the differing viewpoints of the states composing it are not likely to disappear. Even admitting that such a federation is established,

27 See Gasparini, 1983, pp. 203-228. 
what sort of future lies in store for it? The new variables putting the European federation to the test may include radical and unexpected changes in the environment, the consolidation of national economic interests previously softened by the commitment needed to maintain the new state, unstable internal balances which may bring variable geometries back to differentiate between parts of Europe, attractions to external neighbours such as the US for Britain, Russia for central Europe, the Mediterranean basin for southern Europe, the maintenance of states' right of secession - but above all a collaboration fatigue, a tiredness of being together. ${ }^{28}$

Such fatigue has played an important role in previous administrative and political unions. Town councils which have united have subsequently wished to regain their autonomy; parts of provinces (such as Imperia in Italy) have wanted their own autonomy. The same may happen with regions and states set up on the basis of aggregations subsequently considered to be unnatural, artificial and shortterm. There is no doubt that countervailing forces attenuate this tiredness of being together: the inertia deriving from the habit of living together, the fact of having regulated co-existence with efficient and effective institutions, and a system of infrastructure providing close connection. But there are examples in Europe of states which have broken up, and therefore failed, after a time of co-existence: Czechoslovakia, Yugoslavia and the Soviet Union. Others are tempted to break up, such as Belgium, Britain, Spain and even Italy, with ambitions of varying degrees of credibility for a Free State of Trieste, a Padania of the Northern League and an independent Sardinia and Friuli.

At any rate, in the federated Europe the fatigue of living through a common experience starts to produce destructive effects when things (above all the economy, producing problems of identity and neo-nationalism) go wrong and there begins a process, whose speed will depend on external variables, leading to the break-up of the United Europe. Processes similar to the development of tiredness with a Europe too peaceful, too bourgeois, too Belle Époque, led to a desire for social and cultural novelty and a new society at the turn of the $19^{\text {th }}$ century, which in turn led to the enthusiasm greeting the outbreak of the First World War as the beginning of the rebirth of moribund social orders and societies.

Having factored in the times of the four scenarios, we may now rationalise the process whereby they may evolve from 2020 to 2050, postulating (merely for conventional purposes) that until 2040 the environment external to the United Europe remains basically static.

The table below is a schematic presentation of the possible development of the four United Europe scenarios over forty years of prediction.

28 Chiti-Batelli, 2004, pp. 573-589. 


\begin{tabular}{|c|c|c|c|c|}
\hline $\begin{array}{l}\text { Year } \\
\text { of pre- } \\
\text { diction }\end{array}$ & $\begin{array}{l}\text { Return to states } \\
\text { (Pure catastrophic } \\
\text { scenario) }\end{array}$ & $\begin{array}{l}\text { Return to Free } \\
\text { Trade Area (Rea- } \\
\text { listic catastrophic } \\
\text { scenario) }\end{array}$ & $\begin{array}{l}\text { Equilibrium between } \\
\text { the political Europe } \\
\text { in the short term and } \\
\text { a federation in the } \\
\text { long term (Realistic } \\
\text { ideal scenario) }\end{array}$ & $\begin{array}{l}\text { New federal state } \\
\text { (Pure ideal scenario) }\end{array}$ \\
\hline 2020 & $\begin{array}{l}\text { - Economic Eu- } \\
\text { rope and of civil } \\
\text { societies, } \\
\text { - European cen- } \\
\text { tral institutions } \\
\text { (technocratic/ } \\
\text { rigid-contested) }\end{array}$ & $\begin{array}{l}\text { - Political and eco- } \\
\text { nomic Europe and } \\
\text { of civil societies } \\
\text { - European central } \\
\text { institutions }\end{array}$ & $\begin{array}{l}\text { - Economic Europe } \\
\text { and of civil societies } \\
\text { - European central } \\
\text { institutions }\end{array}$ & $\begin{array}{l}\text { - Economic Europe } \\
\text { and of civil societies } \\
\text { - European cen- } \\
\text { tral institutions in } \\
\text { consolidation }\end{array}$ \\
\hline 2030 & $\begin{array}{l}\text { - Dialogues among } \\
\text { states } \\
\text { - European cen- } \\
\text { tral institutions in } \\
\text { demobilisation }\end{array}$ & $\begin{array}{l}\text { - Economic Eu- } \\
\text { rope and of civil } \\
\text { societies } \\
\text { - European cen- } \\
\text { tral institutions in } \\
\text { demobilisation }\end{array}$ & $\begin{array}{l}\text { - Political and eco- } \\
\text { nomic Europe and } \\
\text { of civil societies, but } \\
\text { partial } \\
\text { - European central } \\
\text { institutions }\end{array}$ & $\begin{array}{l}\text { - Political and eco- } \\
\text { nomic Europe and of } \\
\text { civil societies } \\
\text { - European central } \\
\text { institutions, with } \\
\text { political powers }\end{array}$ \\
\hline 2040 & \begin{tabular}{|l|} 
- States revert to \\
separate status \\
- Mainly economic \\
Europe with inter- \\
nal colonialism
\end{tabular} & $\begin{array}{l}\text { - Europe of civil } \\
\text { societies } \\
\text { - European cen- } \\
\text { tral institutions in } \\
\text { demobilisation }\end{array}$ & $\begin{array}{l}\text { - Political and eco- } \\
\text { nomic Europe and of } \\
\text { civil societies } \\
\text { - European central in- } \\
\text { stitutions with internal } \\
\text { soft power functions }\end{array}$ & $\begin{array}{l}\text { - Europe as a federal } \\
\text { state } \\
\text { - European central } \\
\text { institutions in a fed- } \\
\text { eral state }\end{array}$ \\
\hline \multicolumn{5}{|c|}{ The United Europe environment becomes less static, indeed radical events occur } \\
\hline 2050 & $\begin{array}{l}\text { Return to a new } \\
\text { united Europe }\end{array}$ & $\begin{array}{l}\text { Strengthening of } \\
\text { European central } \\
\text { institutions }\end{array}$ & $\begin{array}{l}\text { Experience of new in- } \\
\text { ternational and federal } \\
\text { state soft power }\end{array}$ & $\begin{array}{l}\text { Negative epilogue of } \\
\text { the federal state vs. } \\
\text { Strengthening of the } \\
\text { federal state }\end{array}$ \\
\hline
\end{tabular}

\section{Evolution of the scenarios}

Observed over the next thirty years $(2020,2030,2040)$, the four scenarios are highly linear in their sequence, comprised between the two extremes of a reversion to states, which at the most are joined in a Free Trade Area (Pure catastrophic scenario), and the formation of a federal state (Pure ideal scenario), with the crucial element of internal soft power which frees resources for international soft power, whose methods and potential the Europe of civil societies has already experienced. These two scenarios are explained and represented by an intergovernmental model $^{29}$ and at the opposite extreme a federal approach ${ }^{30}$, a model of bottom-up political change in which enlightened elites and their populations build a grand European project. In these models a central role is played by the civil societies of

29 Sandholtz and Stone Sweet, 1997, pp. 297-317; Rosamond, 2000.

30 O’Neill, 1996. 
individual states and of United Europe (global civil society), in which elites and the population as a whole are inextricably linked.

Beyond these two extremes, what is much more likely is the emergence of a scenario combining a number of characteristics of the two realistic scenarios (the second and the third, catastrophic and ideal). We may consider it as a fifth scenario, a realistic synthesis of the two intermediate ones.

Although everything is predicted to happen between 2010 and 2040, the plausibility of the dynamics and timescales in the scenarios is based and developed in the present United Europe, in physiological enlargement or in reduction.

These internal scenarios assume a basically static external environment in which all movements occur in accordance with predicted rules, at least without radical or violent external changes. But this cannot be taken for granted, since recent years have seen an unforeseen change in the form of the 2008 financial crisis generated by the United States. It has produced turmoil in the economies and globalisation processes of the United Europe and its banking systems, an increase in government bond yield spreads and an impoverishment of the lower-middle classes, in southern and Danubian Europe in particular. Further changes may also occur in the next 30-40 years, and their unpredictability is at the root of crises which may strike at the process of integration of the European Union.

To such changes, which are unpredictable at least in their practical manifestations, the addition of at least another two may be postulated: 1) profound economic, political and power-relationship changes between some emergent nations (China, India, Brazil and the new Russian Federation) and the United Europe, which is increasingly marginalised along with the United States and Japan; 2) a profound subversion of Europe by Islamic fundamentalism and possible terrorism coming from north and sub-Saharan Africa. The first countries to be involved are in southern Europe.

These events, and others not now foreseeable, produce strong impulses in two directions - the dissipation of this new United Europe's energy and reorganisation and close integration within it. As a synthesis we project the four above scenarios to 2050, ten years after 2040, when the United Europe was designing its future based on its own strength and internal processes in a static external environment.

As seen in the schematic presentation above, 2050 shows some profound changes in the United Europe: in the pure catastrophic scenario there is a reversion to single European states; in the pure ideal scenario the United Europe is at a fork - in one direction is a negative epilogue of the break-up of the federation and in the other the strengthening of the federal state to face new external challenges threatening the disintegration of a United Europe which is no longer federal but a single unitary state. 


\section{In the end will this United Europe be achieved or will there be other united Europes?}

The above question may also be expressed as follows: in a hundred years (from 1950 to 2050) the United Europe has produced a basic imprint which in the first 50 years (from 1950 to 2000) we desired and sought. Will it last for the next 50 years (from 2000 to 2050)? Or will this United Europe collapse and follow a new reunification process because (say) the last 50 years have seen the dominance of some EU states such as Germany, or Germany and France, which is unacceptable to medium-small states, who see it as a new colonialism hiding behind the standardised rules of the European institutions?

The construction of a United Europe takes a long time because it involves states which each have their own long political history. However, there are two observations which run counter to this long-term factor. The first is that this United Europe was conceived and began to be built sixty years ago (formally in 1957), so a great many unifying factors have already been put in place. Secondly, before any political government, Europe is united by national civil societies which are increasingly standardised to a European norm. This points to a radically new future direction, towards the possible demise of the present United Europe and towards the emergence of new possible future models of United Europes.

Previous united Europes entered into crisis, and then collapsed, when their principal social structures (feudalism, and then the bourgeoisie) fell into decline. In the present United Europe the principle social structures are its civil societies, whose outlook has extended beyond their national cocoons since national traditions began to lose their hold in the 1970s.

Until the early 1990s the principal social structure of this United Europe of civil societies was hampered by a series of factors: 1) the existence of many frontiers, some of which were hard; 2) a less international dimension in relations between organisations; 3) civil societies were still largely nation-centred; 4) there was still a gap between cosmopolitan elites and the rest of the population, which was localist; 5) there were two types of cosmopolitanism, one excessively orientated towards the US, the other excessively orientated towards the USSR.

In the subsequent decades these civil societies became less national and more European, firstly because the financing and directives of the ECSC, EEC and EU progressively promoted the standardisation of national societies, states and European civil society. Secondly, national identities have not been a particularly difficult obstacle because they have been overlaid by the new European identity, including that of belonging to cross-border areas.

In the future of what is now a United Europe it is thus unlikely that Europeorientated civil societies and the European civil societies will decline as did the feudal system and 18th- and 19th-century bourgeois society. 
On the contrary, this European civil society (and its outward-looking national civil societies) is opening up and absorbing new dimensions based on the values of peace (referred to above), social justice, human rights and openness to the outside but also from the outside to the inside. There is also an increasing awareness of the value of protecting populations which manage to adapt to new situations, but also of the value of protecting populations which are poor and marginalised because of migration and marginalised and impoverished by "development models" old and new. ${ }^{31}$

\section{References}

Acemoglu, Daron and Robinson, James A., (2013), Perchè le nazioni falliscono, Milano, Il Saggiatore

Albertini, Mario, (1997), Lo stato nazionale, Bologna, Il Mulino.

Ash, Timothy Garton, (2005), Free World. America, Europa e il future dell'Occidente, Milano, Mondadori

Baldocci, Pasquale Antonio and Gasparini, Alberto, (2007), L'Europa in bilico/ L'Europe en suspens, Quaderni di Futuribili, no. 9.

Baletic, Zvonimir, (1998), "Europa unita, un lungo cammino", in Petrovic, Rade and Russo, Francesco (eds.), L'altra Europa, Napoli, Edizioni Scientifiche Italiane, 225-230.

Bauman, Zygmunt, (2005), La società sotto assedio, Roma, Laterza.

Bocchi, Gianluca, Ceruti, Mauro and Morin, Edgar, (1991), L'Europa dell'era planetaria, Milano, Sperling and Kupfer.

Censis, (1991), L'Europa del sociale. Un processo di integrazione dal basso, Milano, Angeli.

Chiti-Batelli, Andrea, (2004), "Perplessità sull'avvenire dell'Unione Europea", in Affari Esteri, no. 143.

Dolghi, Dorin Joan, Rouet, Gilles and Radics, Zsolt, (eds.), (2009), "Europe and the neighborhood", in Eurolimes, vol. 7.

Ferraris, Luigi Vittorio, (2001), "La "Dieta perpetua" come congresso permanente di diplomatici", in Futuribili, no. 1-2, 74-85.

Fine, Robert, (2007), Cosmopolitanism, New York, Routledge.

Galtung, Johan, (1994), "L'emergente super-nazionalismo europeo", in Futuribili, vol. 1, no. 1, 129-143.

Gasparini, Alberto, (1983), Ambiente operativo e azienda agricola, Milano, Angeli.

Gasparini, Alberto, (ed.), (1999), Scenari di conflittualità futura. Assetti geopolitici e gestione della crisi nei prossimi dieci anni, Roma, Cemiss

Gasparini, Alberto, (2000), "Prediction and futures studies", in Borgatta, Edgar Frances and Montgomery, Rhonda, (eds.), Encyclopedia of sociology, New York, MacMillan, 2224-2233.

Gasparini, Alberto, (ed.), (2002), "Disoccupazione. Il lato oscuro dello sviluppo", in Futuribili, no. 3.

Gasparini, Alberto, (ed.), (2004a), Gli Europei e la Costituzione ci sono, a quando l'Europa?/ The Europeans and the Constitution are in place - when will Europe be?, Quaderni di Futuribili, no. 5 .

Gasparini, Alberto, (2004b), "Significati d'Europa", in Gasparini, Alberto, (ed.), Gli Europei e la Costituzione ci sono, a quando l'Europa?/ The Europeans and the Constitution are in place - when will Europe be?, Quaderni di Futuribili, no. 5, 73-98.

31 Gasparini, 2002. 
Gasparini, Alberto, (2004c), "La previsione. Modi e temi italiani”, in Futuribili, no. 3.

Gasparini, Alberto, (2007), "Euroregione e confini virtuali. Luoghi internazionali in cui si elabora l'integrazione europea", in Baldocci, Pasquale Antonio and Gasparini, Alberto (eds.), L'Europa in bilico/L'Europe en suspens, Quaderni di Futuribili, no. 9, 9-40

Gasparini, Alberto, (2011), Società civile e relazioni internazionali, Bologna, Il Mulino.

Gasparini, Alberto, (2012), SWOT 3. Cross-border co-operation in Europe. A comprehensive overview, Strasbourg, Council of Europe.

Gasparini, Alberto and Bregantini, Luca, (2004), "Scenari al 2010 per i paesi di recente entrata e di prossima candidatura nell'Unione Europea", in Futuribili, no. 3, 264-305.

Gasparini, Alberto and Radojkovic, Miroljub, (eds), (1994), "Oltre le guerre balcaniche. Cosa può succedere quando i piccoli dei hanno grandi sogni”, in Futuribili, vol. 1, no. 2.

Gatto, Ludovico, (1995), Il federalismo, Roma, Newton Compton.

Geertz, Clifford, (1998), Mondo globale, mondi locali, Bologna, Il Mulino.

Gehring, Thomas, (1996), "Integrating integration theory. Neo-functionalism and international regimes", in Global Society, vol. 10, no. 3, 225-253.

Giubboni, Stefano, (2004), “L'Europa sociale ed il Trattato costituzionale. Luci e ombre”, in Gasparini, Alberto, (ed.), Gli Europei e la Costituzione ci sono, a quando l'Europa?/ The Europeans and the Costitution are in place - when will Europe be?, Quaderni di Futuribili, no 5, 99-116.

Gruppo di Lisbona, (1994), I limiti alla competitività, Roma, Cnel.

Haas, Ernst, (1958), The uniting of Europe, Stanford, Stanford University Press.

Haas, Ernst, (1961), "International integration. The European and the universal process", in International Organization, vol. 15, no. 3, 366-392.

Hughes, Barry B., (1999), International futures. Choice in the face of uncertainty, Boulder Col., Westview Press.

Kornai, János, (2008), From socialism to capitalism, Budapest, Central European University Press.

Langer, Josef, (2011), "Europe 2030: anticipating nation, border and society", in Langer, Josef, (ed.), Analysis and visions for Europe, Frankfurt am Main, Peter Lang GmbH, 31-60.

Lindberg, Leon, (1963), The political dynamics of European integration, Stanford, Stanford University Press.

Miglio, Gianfranco and Barbera, Augusto, (2008), Federalismo e secessione, Milano, Libero

Montanari, Arianna, (2004), "L'identità europea e i valori occidentali", in Gasparini, Alberto, (ed.), Gli Europei e la Costituzione ci sono, a quando l'Europa?/ The Europeans and the Constitution are in place - when will Europe be?, Quaderni di Futuribili, no. 5, 43-72.

Nye, Joseph, (2005), Soft power, Torino, Einaudi.

O’Neill, Michael, (1996), The politics of European integration, New York, Routledge.

Petrovic, Rade and Russo, Francesco, (eds.), (1998), L'altra Europa. L'Europa centrale e $i$ Balcani verso l'Unione Europea, Napoli, Edizioni Scientifiche Italiane.

Puşcaş, Vasile, (2006), European negotiations. A case study: Romanian accession to the European Union, Quaderni di Futuribili, no. 7.

Puşcaş, Vasile, (2013), EU accession negotiations (A handbook), Vienna, Hulla and Co. Human Dynamics KG.

Radermacher, Franz Josef, (2004), Balance or destruction, Vienna, Oekosoziales Forum Europa.

Randers, Jorgen, (2013), 2052. Scenari globali per i prossimi quarant'anni, Milano, Edizioni ambiente.

Rifkin, Jeremy, (2004), Il sogno europeo, Milano, Mondadori. 
Rinaldi, Niccolò, (1995), "L'immagine dell'Europa nel mondo", in Bettin Lattes, Gianfranco, (ed.), La società degli Europei, Bologna, Monduzzi, 327-350.

Rosamond, Ben, (2000), Theories of European integration, Houndsmills, MacMillan

Sandholtz, Wayne and Stone Sweet, Alec, (1997), "European integration and supranational governance”, in Journal of European Public Policy, no. 4, 297-317.

Scartezzini, Riccardo, (2002), "Cittadinanza europea e identità nazionali", in Bettin Lattes, Gianfranco, (ed.), Bologna, Monduzzi, 377-400.

Shelley, Monica and Winck, Margaret, (eds.), (1995), Aspects of European cultural diversity, New York, Routledge.

Sidjanski, Dusan, (2007), Une vision futurible de la Constitution federative européenne", in Baldocci, Pasquale Antonio and Gasparini, Alberto, (eds.), L'Europa in bilico/ L'Europe en suspens, Quaderni di Futuribili, no.9, 87-110.

Spinelli, Altiero, (2010), "Gli Stati Uniti d'Europa e le varie tendenze politiche”, in Spinelli, Altiero and Rossi, Ernesto, (eds.), Il Manifesto di Ventotene, Milano, RCS, 39-72.

Wilson, Jeanne L., (2012), Soft power. A comparisons of discourse and practice in Russia and China. Working Paper Series, SSRN eLibrary (http://ssrn.com/abstract=2134457). 
